\title{
Microdetermination of Double-stranded DNA by Linear Sweep Voltammetry with Phenosafranine
}

\author{
Wei Sun, ${ }^{\dagger}$ Jiayu You, Xuan Hu, and Kui Jiao \\ College of Chemistry and Molecular Engineering, Qingdao University of Science and Technology, \\ Qingdao 266042, The People's Republic of China
}

\begin{abstract}
A novel voltammetric method for the determination of microamounts of fish sperm double-stranded (ds) DNA based on its interaction with phenosafranine (PSF) is proposed in this paper. In a pH 3.5 Britton-Robinson (B-R) buffer solution, PSF had a well-defined second-order derivative linear-sweep voltammetric reductive peak at $-0.32 \mathrm{~V}$ ( $v s$. SCE) on a mercury electrode. After the addition of dsDNA into the PSF solution, the reductive peak current decreased significantly without a shift of the peak potential, and no new peak appeared. The experiment results showed that a new supramolecular complex was formed after the interaction of dsDNA with PSF, which resulted in a decrease of the diffusion coefficient, and then a decrease of the reductive peak current. The interaction conditions and the electrochemical detection conditions were carefully investigated. Under the optimal conditions, the decrease of the peak current was proportional to the dsDNA concentration in the range $1.0-40.0 \mu \mathrm{g} / \mathrm{mL}$ with the linear regression equation $\Delta I_{\mathrm{p}}{ }^{\prime \prime}(\mathrm{nA})=32.59 C(\mu \mathrm{g} / \mathrm{mL})-4.03(n=13, \gamma=0.998)$ and a detection limit of $0.25 \mu \mathrm{g} / \mathrm{mL}(3 \sigma)$. The interaction mechanism was considered based on the aggregation of the dsDNA-PSF supramolecular complex; the stoichiometry of this supramolecular complex was calculated based on voltammetric data with a binding number of 3 and a binding constant of $2.76 \times 10^{12}$. This method was successfully applied to the determination of synthetic samples and the polymerase chain reaction (PCR) product of the nopaline synthase gene (NOS) DNA from genetically modified organisms (GMOs) with satisfactory results.
\end{abstract}

(Received August 30, 2005; Accepted February 9, 2006)

Determining the content of deoxyribonucleic acid (DNA) is very important in mutation detection and clinical diagnostics. Up to now, many methods, ${ }^{1-5}$ such as spectrophotometry, fluorometry and radioactive labeling, have been proposed to determine DNA, but the spectrophotometric method is limited by its low sensitivity, while radioactive labeling method is harmful to the operator and environment with expensive equipment. As for the fluorometric method, it also often suffers from inherent interferences from proteins and other compounds in biological samples. Recently, the light-scattering technique has been extensively studied and applied to the determination of biomacromolecules, such as protein and DNA..$^{6-8}$ Many cationic meso-substituted small molecules, such as neutral red, ${ }^{9}$ methylene blue ${ }^{10}$ etc. had been proposed to determine the content of DNA.

Compared with other analytical methods, the electrochemical method is useful for investigating the binding reaction of small molecules with biomacromolecules. Because the electrochemical reaction occurs on the electrode/liquid surface, it is especially suitable for a small amount of sample with a low detection limit and a wide dynamic range. The interactions of dyes, drugs and metal complexes with DNA and proteins have been widely studied using different electrochemical techniques, ${ }^{11-17}$ which are used to provide a useful method to investigate the binding mode of small molecules with DNA and to explain the anti-tumor mechanism, or have been used as the indicator for an electrochemical DNA biosensor. Recently, Tamiya et al. reported the interaction of Hoechst 33258 with DNA in solution

$\doteqdot$ To whom correspondence should be addressed.

E-mail: sunwei_1975@public.qd.sd.cn by linear-sweep voltammetry, which resulted in a decrease in the anodic signal of Hoechst 33258 on a glassy carbon electrode, and was further used for electrochemical DNA quantification. ${ }^{18}$

In the present work, phenosafranine (PSF), which is a cationic dye with a planar and rigid structure, was used as an electrochemical probe for dsDNA detection. The molecular structure of PSF is shown in Fig. 1; it had been used in a lightscattering technique for the detection of dsDNA. ${ }^{19}$ The interaction of PSF with dsDNA in solution caused changes in the voltammetric response, which was further developed as a new method for the determination of dsDNA. The optimum conditions, the interferences for selectivity and the binding mechanism were carefully studied. This proposed method was further applied to the determination of synthetic samples and a polymerase chain reaction (PCR) product of the nopaline synthase gene (NOS) with satisfactory results.

\section{Experimental}

\section{Reagents}

A stock standard solution of natural herring fish sperm double-stranded DNA (dsDNA, Beijing Jingke Biochemical Company) was prepared by dissolving it in doubly distilled water and kept at $0-4^{\circ} \mathrm{C}$. The concentration of dsDNA was determined by spectrophotometry according to the UV absorbance at $260 \mathrm{~nm}$ after establishing that the absorbance ratio of $A_{260} / A_{280}$ was in the range of $1.80-1.90$, which indicated that the dsDNA was sufficiently free of protein. The molarities of dsDNA were calculated by using $\varepsilon_{\mathrm{DNA}}=6600 \mathrm{~L} / \mathrm{mol} \mathrm{cm}$. The 
<smiles>Nc1ccc2nc3ccc(=NCl)cc-3n(-c3ccccc3)c2c1</smiles>

Fig. 1 Molecular structure of phenosafranine.

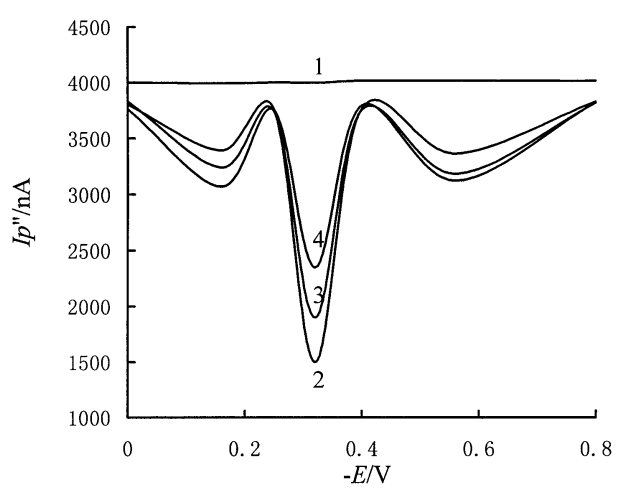

Fig. 2 Second-order derivative linear sweep voltammograms of PSF in the absence and presence of dsDNA. 1, pH 3.5 B-R buffer; 2 , $1+2.0 \times 10^{-4} \mathrm{~mol} / \mathrm{L}$ PSF; $3,2+10.0 \mu \mathrm{g} / \mathrm{mL}$ dsDNA; $4,2+20.0$ $\mu \mathrm{g} / \mathrm{mL}$ dsDNA.

denatured single-stranded DNA (ssDNA) was obtained by heating native fish sperm dsDNA in $100^{\circ} \mathrm{C}$ water for $10 \mathrm{~min}$, and rapidly cooling in an ice-water bath. A $1.0 \times 10^{-3} \mathrm{~mol} / \mathrm{L}$ phenosafranine (PSF, Tianjin Damao Chemical Reagent Station) stock solution was prepared by dissolving $0.03230 \mathrm{~g}$ of PSF in $100 \mathrm{~mL}$ of water. Then, a $0.2 \mathrm{~mol} / \mathrm{L}$ Britton-Robinson (B-R) buffer solution was used to control the acidity of the interaction solution. All other reagents were of analytical reagent grade and used without further purification. Doubly distilled water was used throughout.

\section{Instruments}

All of the cyclic voltammetric experiments were carried out using a DS Model 2004 electrochemical analyzer (Shandong Dongsheng Electronic Instrument, China) with a DS-991 static mercury drop working electrode (Shandong Dongsheng Electronic Instrument, China), a saturated calomel reference electrode (SCE) and a platinum wire auxiliary electrode. A second-order derivative linear-sweep voltammetric determination was obtained on a Model JP-303 polarographic analyzer (Chengdu Apparatus Factory, China) with a traditional three-electrode system composed of a dropping mercury working electrode (DME), a saturated calomel (SCE) reference electrode and a platinum wire auxiliary electrode. UV-Visible absorption spectra were recorded by a Cary Model 50 probe spectrophotometer (Varian, Australia). PCR amplification was performed on a standard Eppendorf Mastercycler Gradient PCR system (Germany). A pHS-25 acidimeter (Shanghai Leici Instrument Factory, China) was used to measure the values of the buffer $\mathrm{pH}$. All of the experiments were carried out at $25 \pm 2^{\circ} \mathrm{C}$, except when otherwise stated.

\section{Procedure}

In a $10 \mathrm{~mL}$ colorimetric flask, $2.5 \mathrm{~mL}$ of a $0.2 \mathrm{~mol} / \mathrm{L} \mathrm{pH} 3.5$ B-R buffer solution, $2.0 \mathrm{~mL}$ of a $1.0 \times 10^{-3} \mathrm{~mol} / \mathrm{L}$ PSF solution

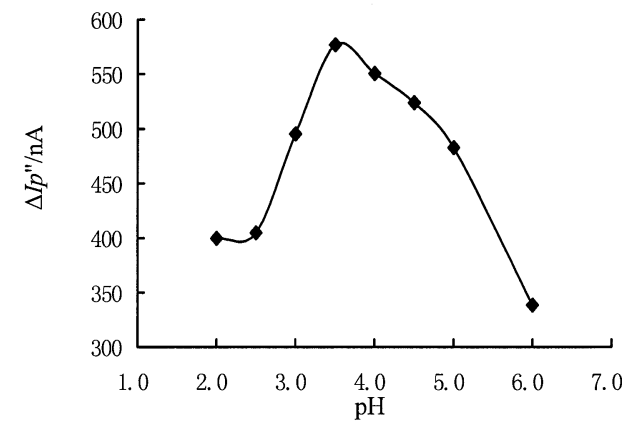

Fig. 3 Influence of the $\mathrm{pH}$ on the peak current. $2.0 \times 10^{-4} \mathrm{~mol} / \mathrm{L}$ $\mathrm{PSF}+10.0 \mu \mathrm{g} / \mathrm{mL}$ dsDNA in different $\mathrm{pH}$ B-R buffer solutions.

and an appropriate amount of a dsDNA solution or sample solutions were added in sequence. The mixtures were diluted to $10 \mathrm{~mL}$ with water and mixed homogeneously. The final solution was reacted at $25^{\circ} \mathrm{C}$ for $20 \mathrm{~min}$. The voltammograms were scanned in the potential range $0--0.8 \mathrm{~V}$ ( vs. SCE) and the voltammetric reductive peak current at $-0.32 \mathrm{~V}$ was recorded. Because the oxygen has two reduction peaks at $-0.2 \mathrm{~V}$ and -0.8 $\mathrm{V}$, which has a little influence on the peak current of PSF, it is unnecessary to deaerate the reaction solution. Under the same conditions, the peak current without the addition of dsDNA $\left(I_{\mathrm{p}_{\mathrm{o}}}\right)$ was also recorded and the differences in the peak current, $\Delta I_{\mathrm{p}}\left(I_{\mathrm{p}_{\mathrm{o}}}-I_{\mathrm{p}}\right)$, was used to determine the concentration of dsDNA.

\section{Results and Discussion}

\section{Second-order derivative linear sweep voltammogram}

In order to improve the sensitivity of detection, second-order derivative linear sweep voltammetry (LSV) was used in this experiment with a JP-303 polarographic analyzer. The typical linear-sweep voltammograms of the reaction solution are shown in Fig. 2. Curve 1 is a voltammogram of the buffer solution; no voltammetric peak appears. Curve 2 is a voltammogram of the PSF solution; it has a well-defined voltammetric reductive peak at $-0.32 \mathrm{~V}$ ( vs. SCE), which belongs to electrode reduction of the pyrazine group in the structure of PSF. Curves 3 and 4 are voltammograms of a mixture of PSF with different amounts of dsDNA. Owing to the addition of dsDNA, a supramolecular complex was formed, which resulted in a decrease of the diffusion coefficient of the reaction solution, and thus a decrease in the reductive peak current was found. The more the dsDNA was added, the greater did the reductive peak current decrease, which could be further used to detect dsDNA.

\section{Optimization of the experimental conditions}

The microenvironment of the dye and the conformation of dsDNA were greatly influenced by the $\mathrm{pH}$ of the buffer solution; the optimal $\mathrm{pH}$ for the binding reaction was selected in the $\mathrm{pH}$ range of $2.0-6.0$. The result is shown in Fig. 3; it can be seen that at $\mathrm{pH} 3.5$ the difference in the peak current reached its maximum, and thus a pH 3.5 B-R buffer solution was used throughout this experiment. In an acidic aqueous solution of $\mathrm{pH}$ 3.5 , the PSF species was positively charged and the phosphate bones of dsDNA were negatively charged. Thus the electrostatic force was primarily responsible for the binding of PSF with dsDNA. The effect of different kinds of buffers, such as $\mathrm{B}-\mathrm{R}, \mathrm{HOAC}-\mathrm{NaOAC}$ and $\mathrm{NH}_{3}-\mathrm{NH}_{4} \mathrm{Cl}$, were tested and in a $\mathrm{B}-\mathrm{R}$ buffer solution the response was maximum. Thus the $\mathrm{pH}$ 3.5 B-R buffer is recommended in this paper. 
Table 1 Influence of coexisting substances on the determination of $10.0 \mu \mathrm{g} / \mathrm{mL}$ dsDNA

\begin{tabular}{lcr}
\hline Coexisting substance & Concentration/mol L-1 & Relative error, $\%$ \\
\hline $\mathrm{Ba}^{2+}$ & $1.0 \times 10^{-5}$ & 4.55 \\
$\mathrm{Fe}^{3+}$ & $1.0 \times 10^{-5}$ & 4.55 \\
$\mathrm{Cd}^{2+}$ & $1.0 \times 10^{-5}$ & -1.52 \\
$\mathrm{Ni}^{2+}$ & $1.0 \times 10^{-5}$ & 3.04 \\
$\mathrm{Hg}^{2+}$ & $1.0 \times 10^{-5}$ & 3.04 \\
$\mathrm{~Pb}^{2+}$ & $1.0 \times 10^{-5}$ & -3.24 \\
$\mathrm{Co}^{2+}$ & $1.0 \times 10^{-5}$ & 3.54 \\
$\mathrm{Cu}^{2+}$ & $1.0 \times 10^{-5}$ & 2.83 \\
$\beta$-CD & $1.0 \times 10^{-5}$ & 4.95 \\
$\mathrm{CTAB}$ & $1.0 \times 10^{-5}$ & -78.95 \\
$\mathrm{SDS}$ & $1.0 \times 10^{-5}$ & -55.65 \\
$\mathrm{Citric}$ acid & $10.0 \mu \mathrm{g} \mathrm{mL}^{-1}$ & 3.33 \\
Glucose & $100.0 \mu \mathrm{g} \mathrm{mL}^{-1}$ & -2.24 \\
L-Glycine & $10.0 \mu \mathrm{g} \mathrm{mL}^{-1}$ & 0.00 \\
L-Leucine & $10.0 \mu \mathrm{g} \mathrm{mL}^{-1}$ & -1.01 \\
L-Serine & $10.0 \mu \mathrm{g} \mathrm{mL}^{-1}$ & 3.33 \\
L-Valine & $10.0 \mu \mathrm{g} \mathrm{mL}^{-1}$ & -3.67 \\
L-Tyrosine & $10.0 \mu \mathrm{g} \mathrm{mL}^{-1}$ & -1.10 \\
L-Arginine & $10.0 \mu \mathrm{g} \mathrm{mL}^{-1}$ & -5.00 \\
Heparin & $10.0 \mu \mathrm{g} \mathrm{mL}^{-1}$ & 4.56 \\
HSA & $1.0 \mu \mathrm{g} \mathrm{mL}^{-1}$ & -3.46 \\
BSA & $1.0 \mu \mathrm{g} \mathrm{mL}^{-1}$ & 2.66 \\
\hline
\end{tabular}

HSA, Human serum albumin; BSA, bovine serum albumin.

The effect of the concentration of the buffer solution on the peak current was also investigated. The experiments showed that $\Delta I_{\mathrm{p}}^{\prime \prime}$ reached a maximum when the volume of the $0.2 \mathrm{~mol} / \mathrm{L}$ B-R buffer solution was $2.5 \mathrm{~mL}$ in a $10 \mathrm{~mL}$ portion of the final solution; at this time the concentration of the B-R buffer was $0.05 \mathrm{~mol} / \mathrm{L}$.

The effect of the PSF concentration on the peak current was studied in the range of $5.0 \times 10^{-5}-3.0 \times 10^{-4} \mathrm{~mol} / \mathrm{L}$ with 10.0 $\mu \mathrm{g} / \mathrm{mL}$ dsDNA. The differences in the peak current increased with an increase of the PSF concentration, and reached its maximum at $2.0 \times 10^{-4} \mathrm{~mol} / \mathrm{L}$. When the concentration was higher than this value, the peak current greatly decreased, which may have been due to the complete binding of PSF with dsDNA. Thus, $2.0 \times 10^{-4} \mathrm{~mol} / \mathrm{L}$ of PSF is recommended for use in this paper.

The influence of the incubation time was investigated. After mixing dsDNA with PSF, the binding reaction occurred rapidly. The difference in the peak current reached the maximum value within $20 \mathrm{~min}$, and remained unchanged for at least $2 \mathrm{~h}$. Therefore, this system was stable and practical for the determination of dsDNA.

The effect of the reaction temperature on the interaction was tested in the range of $15-40^{\circ} \mathrm{C}$ with a reaction time of $20 \mathrm{~min}$. The results showed that there were no obvious differences among them. Since the binding reaction reached its equilibrium in $20 \mathrm{~min}$, the reaction temperature was selected as $25^{\circ} \mathrm{C}$ for common use.

The instrumental conditions, such as the scan rate and the standing time of the dropping mercury working electrode for the assay, were studied. The peak current was increased with an increase of the potential scan rate in the range from 100 to 1000 $\mathrm{mV} / \mathrm{s}$, and reached the maximum value at $1000 \mathrm{mV} / \mathrm{s}$. Thus, $1000 \mathrm{mV} / \mathrm{s}$ was selected as the scan rate for detection. The dropping mercury standing time for the assay was also optimized, and selected as $15 \mathrm{~s}$.

\section{Effects of coexisting substances}

Under the optimal conditions, various foreign substances

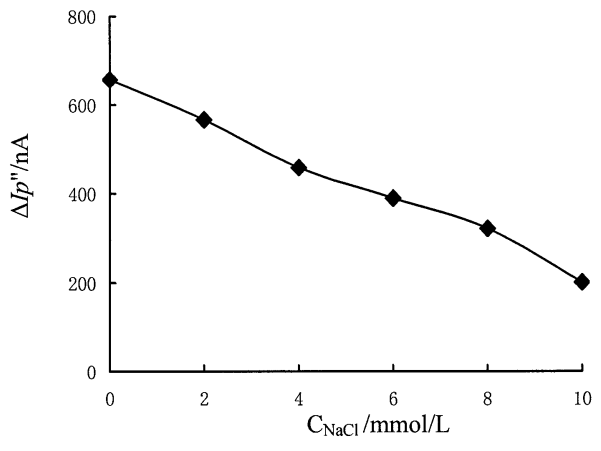

Fig. 4 Influence of the ionic strength on the peak current. $2.0 \times$ $10^{-4} \mathrm{~mol} / \mathrm{L} \mathrm{PSF}+10.0 \mu \mathrm{g} / \mathrm{mL}$ dsDNA in $\mathrm{pH} 3.5 \mathrm{~B}-\mathrm{R}$ buffer solution.

including metal ions, amino acids, glucose and protein, were examined for interference on the determination of $10.0 \mu \mathrm{g} / \mathrm{mL}$ dsDNA; the results are summarized in Table 1. It can be seen that most of them at a given concentration did not interfere with the determination, and good selectivity can be obtained with this method.

The influences of some surfactants, such as sodium dodecyl sulfate (SDS), $\beta$-cyclodextrin $(\beta$-CD) and cetyltrimethylammonium bromide $(\mathrm{CTAB})$, on the binding reaction were also investigated. The addition of non-ionic surfactants, such as $\beta$ $\mathrm{CD}$, seldom affected the binding reaction, but the addition of SDS and CTAB could greatly influence the value of $\Delta I$, which may be explained as meaning that the ionic surfactants dissociated in the solution could compete with PSF to form a surfactant-DNA complex.

\section{Effect of the ionic strength}

In order to investigate the impact of the ionic strength on the interaction, different amounts of $0.2 \mathrm{~mol} / \mathrm{L} \mathrm{NaCl}$ solution were added; the results are shown in Fig. 4. The ionic strength had significant influences on the interaction, and the value of $\Delta I$ decreased with an increase of the salt concentration. Thus the interaction of PSF with dsDNA was caused by a highly favored electrostatic attraction. The addition of $\mathrm{NaCl}$ in the reaction solution was expected to weaken the electrostatic force between PSF and dsDNA. The electrostatic shielding effect of the charges with increasing of $\mathrm{Na}^{+}$concentration greatly weakened the affinity of PSF with dsDNA and more $\mathrm{Na}^{+}$competed with PSF to combine with the negatively charged dsDNA.

\section{Calibration curve}

Based on the decrease of the second-order derivative linearsweep voltammetric peak current, a quantitative method was developed for the determination of dsDNA. A linear relationship between the decrease of the peak currents $\left(\Delta I_{\mathrm{p}}\right)$ with the concentration of dsDNA was established in the concentration range $1.0-40.0 \mu \mathrm{g} / \mathrm{mL}$ with the linear regression equation being $\Delta I_{\mathrm{p}}{ }^{\prime \prime}(\mathrm{nA})=32.59 C(\mu \mathrm{g} / \mathrm{mL})-4.03(\gamma=0.998, n=13)$; here $\gamma$ is the correlation coefficient and $n$ is the number of points. The RSD of 10 parallel determinations of $20.0 \mu \mathrm{g} / \mathrm{mL}$ dsDNA was $3.73 \%$. The detection limit was calculated to be $0.25 \mu \mathrm{g} / \mathrm{mL}$ with the equation $\mathrm{LOD}=3 S_{0} / S$, where 3 is the factor at the $99 \%$ confidential level, $S_{0}$ the standard deviation of the blank measurements $(n=10)$ and $S$ the slope of the calibration curve.

Analysis of synthetic samples and recovery

Synthetic samples containing dsDNA, in which metal ions, carbohydrates, amino acids or protein were deliberately added, 
Table 2 Determination results of dsDNA in synthetic samples $(n=5)$

\begin{tabular}{|c|c|c|c|c|c|}
\hline No. & Foreign coexisting substance & $\begin{array}{l}\text { dsDNA added/ } \\
\mu \mathrm{g} \mathrm{mL}^{-1}\end{array}$ & $\begin{array}{l}\text { Found/ } \\
\mu \mathrm{g} \mathrm{mL}-1\end{array}$ & Rec., \% & $\mathrm{RSD}, \%$ \\
\hline 1 & L-Serine, L-glycine, $\mathrm{Ni}^{2+}$, HSA & 10.0 & 10.13 & $98.1-103.3$ & 2.45 \\
\hline 2 & HSA, $\beta$-CD, L-arginine, glucose & 10.0 & 9.92 & $96.6-101.2$ & 1.84 \\
\hline 3 & Alcohol, $\mathrm{Fe}^{3+}, \mathrm{Ba}^{2+}, \mathrm{Cu}^{2+}$ & 10.0 & 10.01 & $97.8-103.9$ & 2.20 \\
\hline
\end{tabular}

Conditions: L-serine, L-glycine, L-arginine $(10.0 \mu \mathrm{g} / \mathrm{mL})$; HSA $(1.0 \mu \mathrm{g} / \mathrm{mL}) ; \beta$-CD $\left(1.0 \times 10^{-5} \mathrm{~mol} / \mathrm{L}\right)$; glucose $\left(100.0 \mu \mathrm{g} / \mathrm{mL}^{2}\right) \mathrm{Fe}^{3+}, \mathrm{Ba}^{2+}$, $\mathrm{Cu}^{2+}, \mathrm{Ni}^{2+}\left(1.0 \times 10^{-5} \mathrm{~mol} / \mathrm{L}\right)$.

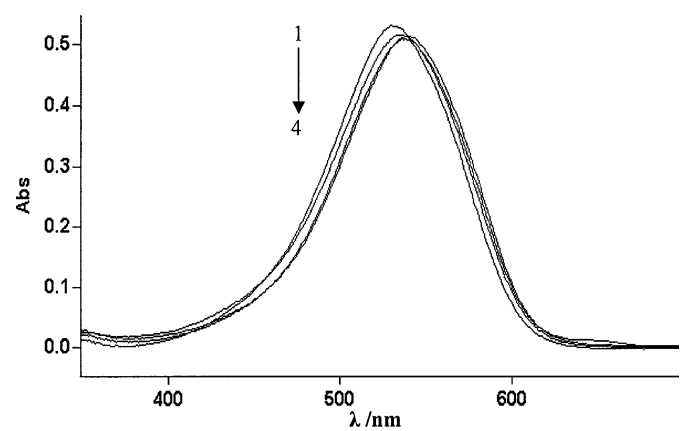

Fig. 5 Absorption spectra of PSF in the absence and presence of dsDNA. 1 , pH 3.5 B-R buffer $+1.0 \times 10^{-5} \mathrm{~mol} / \mathrm{L}$ PSF; $2,1+10.0$ $\mu \mathrm{g} / \mathrm{mL}$ dsDNA; $3,1+15.0 \mu \mathrm{g} / \mathrm{mL}$ dsDNA; $4,1+20.0 \mu \mathrm{g} / \mathrm{mL}$ dsDNA.

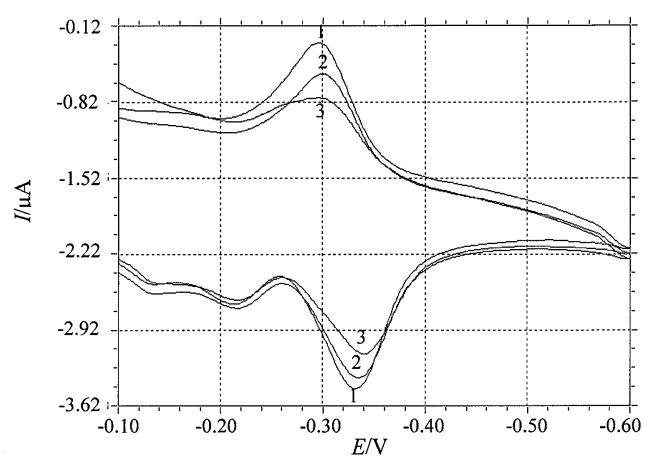

Fig. 6 Cyclic voltammograms of PSF in the absence and presence of dsDNA. $1,1.0 \times 10^{-4} \mathrm{~mol} / \mathrm{L}$ PSF; $2,1+10.0 \mu \mathrm{g} / \mathrm{mL}$ dsDNA; and $3,1+20.0 \mu \mathrm{g} / \mathrm{mL}$ dsDNA. were determined according to a general procedure. The analytical results are given in Table 2 . It can be seen that dsDNA in synthetic samples can be satisfactory determined, and that this assay is accurate, reliable and reproducible.

\section{Determination of PCR product of the NOS gene}

The proposed method was further applied to the determination of the polymerase chain reaction (PCR) product of the NOS gene, which is derived from the nopaline synthase gene from Agrobacterium tumefaciens, and is often used as inserts of genetically modified organisms (GMOs). All of the PCR amplification was performed with a standard procedure using a forward primer of NOS (NOSF) and a reverse primer of NOS (NOSR). The PCR reaction was performed in a final volume of $100 \mu \mathrm{L}$ containing $1.0 \mu \mathrm{g} / \mathrm{mL}$ of the NOS primers, $5 \mu \mathrm{L}$ of 10 mmol $\mathrm{MgCl}_{2}, 20 \mu \mathrm{L}$ of $10 \mu \mathrm{g} / \mathrm{mL}$ deoxyribonucleoside triphosphate $\left(\mathrm{d}_{\mathrm{NTP}}\right), 2 \mu \mathrm{L}$ of tag DNA polymerase, $10 \times$ reaction buffer B (Promega, Wisconsin USA) and $1.0 \mu \mathrm{L}$ of DNA template purified from samples. The tubes were subjected to 30 amplified cycles consisting $95^{\circ} \mathrm{C}$ for $1 \mathrm{~min}$ and $60^{\circ} \mathrm{C}$ for $60 \mathrm{~s}$. After the cycle step, the final extension was lengthened at $70^{\circ} \mathrm{C}$ for $10 \mathrm{~min}$. The concentration of the PCR product was measured by the absorbance at $260 \mathrm{~nm}$, and was calculated as $1.817 \mu \mathrm{g} / \mathrm{mL}$. The results were also compared with that from the electrochemical determination proposed in this paper according to a general procedure by directly mixing suitablely diluted PCR product with the PSF solution. The changes of the voltammetric response were measured, and the concentration value was obtained from the working curve of dsDNA with the result calculated as $1.830 \mu \mathrm{g} / \mathrm{mL}(n=5$; RSD, 2.67\%), which was also close to that from the spectrophotometric determination.

Spectrophotometric and electrochemical studies on the PSF with dsDNA

The interaction mechanism was studied by UV-Vis spectrophotometry and cyclic voltammetry, respectively. Figure 5 shows the UV-Vis absorption spectra of PSF with dsDNA in a pH 3.5 B-R buffer solution. PSF had the maximum absorption at $530 \mathrm{~nm}$, and after the interaction with dsDNA the maximum absorption number moved to $550 \mathrm{~nm}$ with a slight decrease of the absorbance.

According to Barton's report,,$^{20}$ hypochromism and red shift indicate that there is an interaction between the chromophore and DNA. The observed red shift is evidence for the intercalation of PSF molecules into the DNA base stack. Since the PSF species are positively charged, it is easily bonded to the outer negatively charged $\mathrm{PO}_{4}{ }^{3-}$ groups of DNA by at first electrostatic binding. However, because the decrease in the absorbance and the red shift of the wavelength were not very significant, intercalation binding was not predominate. The changes in the absorbance were so weak that UV-Vis spectrophotometry was not suitable for investigating the PSF-DNA interaction system. However, it was found that the interaction caused great changes in the electrochemical response.

Figure 6 shows the cyclic voltammograms of PSF in both the absence and presence of different amounts of dsDNA. It can be seen that PSF had a pair of redox peaks (curve 1) in the potential range of $-0.1--0.6 \mathrm{~V}$. After the addition of DNA into the PSF solution and subsequent scanning over the same potential range, only a sharp decrease of the peak current in both anodic and cathodic waves (curves 2 and 3) appeared without any shift of the peak potential; no new redox peaks appeared. Bard et al..$^{11,21,22}$ reported on the interaction of some metal chelates $\left(\mathrm{ML}_{3}{ }^{3+/ 2+}\right)$, such as $\mathrm{Co}$ (II) and $\mathrm{Fe}$ (III) chelates, with 1,10-phenanthroline and 2,2'-bipyridine bound to DNA via electrochemical methods. Based on the charges of the voltammetric response of the interaction system, the binding constants and binding site sizes were analyzed based on the voltammetric data in detail. Several reviews ${ }^{23-25}$ have thoroughly focused on the various electrochemical approaches of the interactions of drugs, dyes and metal 


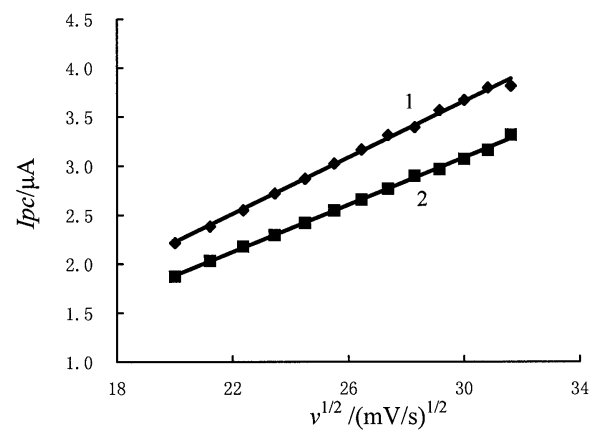

Fig. 7 Dependence of the peak current on the square root of the scan rate. 1 , pH 3.5 B-R buffer $+2.0 \times 10^{-4} \mathrm{~mol} / \mathrm{L}$ PSF; $2,1+10.0$ $\mu \mathrm{g} / \mathrm{mL}$ dsDNA.

complexes with DNA. Changes in the electrochemical signals were shown to be caused by the formation of a small moleculesDNA complex. In this paper, the changes in the cyclic voltammetric curves of PSF in both the absence and presence of DNA also indicated the formation of the PSF-DNA complex.

In order to investigate the binding mechanism of PSF with DNA, the electrochemical behaviors of PSF in the absence and presence of dsDNA were considered. As for the PSF solution, a single-sweep cyclic voltammetric curve (curve 1 of Fig. 6) showed that it had a pair of redox peaks with $E_{\mathrm{pa}}=-0.33 \mathrm{~V}, E_{\mathrm{pc}}$ $=-0.30 \mathrm{~V}(v s . \mathrm{SCE})$ and $I_{\mathrm{pa}} / I_{\mathrm{pc}}=1$. Thus the redox process of PSF on a hanging mercury drop electrode (HMDE) was reversible, and the apparent formal potential $\left(E^{0}\right)$ was calculated to be $-0.315 \mathrm{~V}$, since $E^{0}=\left(E_{\mathrm{pa}}+E_{\mathrm{pc}}\right) / 2$. According to the formula $\Delta E_{\mathrm{p}}\left(E_{\mathrm{pc}}-E_{\mathrm{pa}}\right)=58 / n\left(\mathrm{mV}, 25^{\circ} \mathrm{C}\right)$ and because the experiment result was $30 \mathrm{mV}\left(25^{\circ} \mathrm{C}\right)$, the electron transfer number $(n)$ was calculated to be 2 . In the $\mathrm{pH}$ range from 2.0 6.0 , the relationship between the reductive peak potential with the $\mathrm{pH}$ of the buffer solution was investigated with a linearregression equation of $E_{\mathrm{pc}}=-0.057 \mathrm{pH}-0.22(\gamma=0.996)$. According to the equation $-0.059 x / n=-0.057$, where $n$ is the number of electron transfers and $x$ is the number of hydrogen ions participating in the reaction, the uptake of electrons were accompanied by equal number of hydrogen ions and $x=2$. The proposed mechanism of the electrode process of PSF is given as follows:

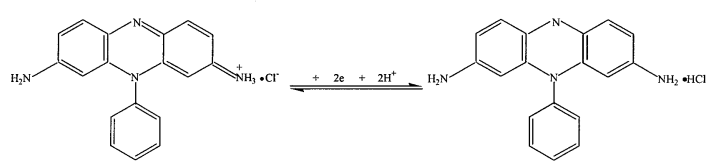

As for the PSF-DNA interaction solution, the cyclic voltammograms were also recorded under the selected experimental conditions, and the results are shown in Fig. 6 (curves 2 and 3). It can be seen that the difference in the peak potential $\left(\Delta E_{\mathrm{p}}\right)$ was also calculated as $30.0 \mathrm{mV}$ with a pair of redox peaks of almost equal peak heights. The relation of peak potential with the $\mathrm{pH}$ of the buffer solution was linear and had a linear-regression equation of $E_{\mathrm{pc}}=-0.065 \mathrm{pH}-0.11(\gamma=0.995)$. Thus, the electron transfer number $(n)$ and the hydrogen ion participating in the electrode reaction $(x)$ were also calculated as $x=n=2$. The results showed that no matter whether dsDNA was present or not, the electrode reaction processes were both two-electron transfer with two-proton uptake.

The relationships of $I_{\mathrm{pc}}$ with the scan rate were examined in both the absence and presence of DNA; a plot is shown in Fig.

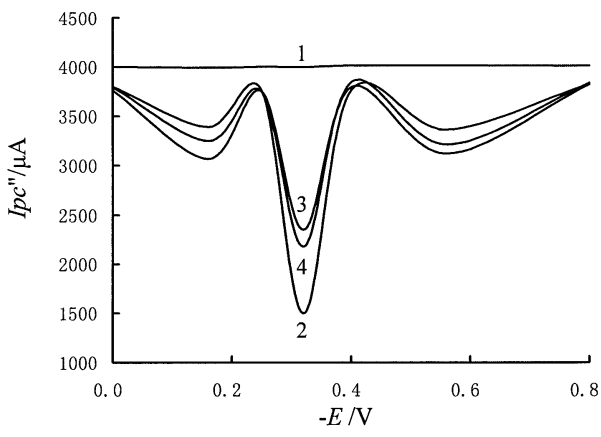

Fig. 8 Linear sweep voltammetric curves of PSF with dsDNA and ssDNA. 1, pH 3.5 B-R buffer; $2,1+2.0 \times 10^{-4} \mathrm{~mol} / \mathrm{L}$ PSF; $3,2+$ $20.0 \mu \mathrm{g} / \mathrm{mL}$ dsDNA; $4,2+20.0 \mu \mathrm{g} / \mathrm{mL}$ ssDNA.

7. The peak current obtained from the PSF and PSF-DNA reaction solution showed a linear dependence on the square root of the scan rate, which indicated that in both the absence and presence of dsDNA, the electrode process was completely controlled by the diffusional mass transport of the electroactive species to the surface of the mercury electrode. The slope of the linear relation $I_{\mathrm{pc}} v s . v^{1 / 2}$ without dsDNA, $142.80 \mathrm{nA} /\left(\mathrm{mV} \mathrm{s}^{-1}\right)^{1 / 2}$, was more than that with dsDNA, $119.97 \mathrm{nA} /\left(\mathrm{mV} \mathrm{s}^{-1}\right)^{1 / 2}$, suggesting that the diffusion coefficient of the free PSF was larger than that of the PSF-dsDNA complex.

The interaction of denatured ssDNA with PSF was also investigated in our experiments; the results are shown in Fig. 8. Compared with dsDNA, ssDNA also showed an appreciable binding reaction with PSF, and a decrease of the cathodic peak current was also observed. Since the main binding force that existed in PSF and dsDNA was an electrostatic force, the phosphate bone of ssDNA can also interact with PSF by the electrostatic force. However, the binding strength was weaker than that of with dsDNA.

According to the above experimental results, the interaction of DNA with PSF does not change with the electrochemical behaviors of PSF; also, the formation of the PSF-dsDNA supramolecular complex resulted in a decrease of the diffusion coefficient of the reaction solution, and a decrease of the reductive peak current of the reaction solution was observed.

\section{Measurement of the stoichiometry of the dsDNA-mPSF}

To determine the composition of the supramolecular complex and the equilibrium constant of the binding reaction, the following equations were used. ${ }^{26}$ It was assumed that PSF interacting with DNA only formed a single complex of DNAmPSF. The binding number and the equilibrium constant of the binding reaction can be deduced as follows:

$$
\mathrm{DNA}+m \mathrm{PSF} \longrightarrow \mathrm{DNA}-m \mathrm{PSF} .
$$

The equilibrium constant was

$$
\beta_{\mathrm{s}}=[\mathrm{DNA}-m \mathrm{PSF}] /[\mathrm{DNA}][\mathrm{PSF}]^{\mathrm{m}} \text {. }
$$

According to the Ilkovic equation, $I_{\mathrm{d}}=708 n D_{\mathrm{o}}{ }^{1 / 2} \mathrm{~m}^{2 / 3} \mathrm{t}^{1 / 6} \mathrm{C}_{\mathrm{o}} *=$ $k C_{\mathrm{o}}{ }^{*}$, the peak current $\left(I_{\mathrm{d}}\right)$ is proportional to the concentration $\left(C_{0}^{*}\right)$, the following equations could be deduced:

$\Delta I_{\mathrm{max}}=k C_{\mathrm{DNA}}$,

$\Delta I=k[\mathrm{DNA}-m \mathrm{PSF}]$ 


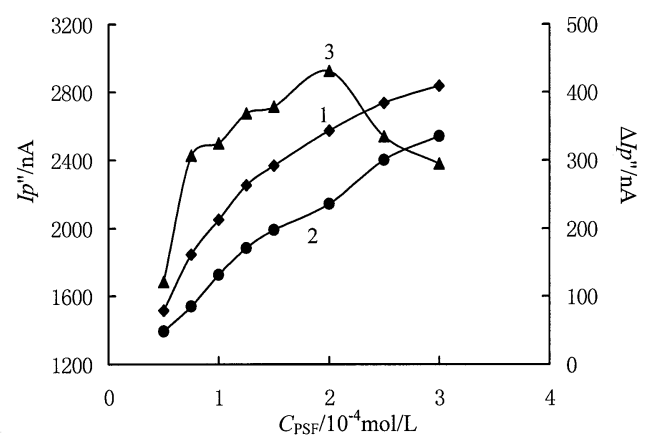

Fig. 9 Relationship between $I_{\mathrm{p}}{ }^{\prime \prime}$ and $C_{\mathrm{PSF}}(1,2), \Delta I_{\mathrm{p}}{ }^{\prime \prime}$ and $C_{\mathrm{PSF}}$ (3). $1, C_{\mathrm{DNA}}=0 ; 2, C_{\mathrm{DNA}}=10.0 \mu \mathrm{g} / \mathrm{mL} ; 3, \Delta I_{\mathrm{p}}^{\prime \prime}=I_{\mathrm{p} 1}{ }^{\prime \prime}-I_{\mathrm{p} 2}{ }^{\prime \prime}$.

$$
[\mathrm{DNA}]+[\mathrm{DNA}-m \mathrm{PSF}]=C_{\mathrm{DNA}}
$$

Therefore,

$$
\Delta I_{\max }-\Delta I=k\left(C_{\mathrm{DNA}}-[\mathrm{DNA}-m \mathrm{PSF}]\right)=k[\mathrm{DNA}] .
$$

Introducing Eqs. (2), (4) and (6) gave

$$
\begin{aligned}
& 1 / \Delta I=1 / \Delta I_{\max }+\left(1 / \beta \Delta I_{\max }\right)\left(1 /[\mathrm{PSF}]^{\mathrm{m}}\right) \text { or } \\
& \log \left[\Delta I /\left(\Delta I_{\max }-\Delta I\right)\right]=\log \beta_{\mathrm{s}}+m \log [\mathrm{PSF}]
\end{aligned}
$$

Here $\Delta I$ is the difference in peak current between the presence and absence of DNA, and $\Delta I_{\max }$ corresponds to the obtained value when the concentration of PSF is extremely higher than that of DNA; $k$ stands for the constant of the Ilkovıc equation, which is proportional to the square root of the diffusion constant $\left(D_{\mathrm{o}}\right) . C_{\mathrm{DNA}},[\mathrm{DNA}]$, [DNA-mPSF] correspond to the total, free and bound concentration of DNA in the solution, respectively.

For minimizing the reading error, the second-order derivative linear sweep voltammetric peak currents were used. From Fig. 2 it can be seen that the shape of the second-order derivative linear sweep voltammetric curves did not change with the addition of dsDNA. The value of $I_{\mathrm{p}}$ " also had a good linear with the concentration of dsDNA, so the above deduced equations were also valid for the second-order derivative linear sweep voltammetric results; Eq. (8) can be used for the following calculation. According to the literature, $\mathrm{Li}$ et al. also applied this method to determine the stoichiometry of the porphyrinDNA ${ }^{26}$ tetraphenyl porphyrin tetrasulfonate-albumin ${ }^{27}$ and 9,10-anthraquinon-hemoglobin ${ }^{28}$ interaction system. In Fig. 9, curve 1 shows the relationship of $I_{\mathrm{p}}{ }^{\prime \prime}$ with the concentration of PSF and curve 2 represents the change in the peak current after the addition of $10.0 \mu \mathrm{g} / \mathrm{mL}$ DNA upon varying the concentration of PSF. Curve 3 shows the differences between curve 1 and curve 2, which represent the relationship between $\Delta I_{\mathrm{p}}{ }^{\prime \prime}\left(I_{\mathrm{p}_{1}}{ }^{\prime \prime}-I_{\mathrm{p} 2}{ }^{\prime \prime}\right)$ and the concentration of PSF. From Eq. (8) the relation of $\log \left[\Delta I /\left(\Delta I_{\max }-\Delta I\right)\right]$ with $\log [\mathrm{PSF}]$ was calculated, with the result being $\log \left[\Delta I /\left(\Delta I_{\max }-\Delta I\right)\right]=12.44+2.84 \times$ $\log [\mathrm{PSF}]$. From the intercept and the slope, $m \approx 3.0$ and $\beta_{\mathrm{s}}=$ $2.76 \times 10^{12}$ were deduced, which indicated that a stable $1: 3$ complex of DNA-3PSF was formed in the desired concentration range of PSF with respect to the concentration of DNA.

In the present work, phenosafranine (PSF) was used as the electrochemical probe for the determination of a microamount of dsDNA. PSF was a kind of cationic dye, and in an acidic solution it was positively charged, while the sugar-phosphate backbones of the dsDNA molecular chains were negatively charged. Thus, there was an electrostatic interaction between the protonated amine group of PSF and the negatively charged phosphate group of dsDNA to form a supramolecular complex, and a decrease of the redox peak current. The decrease of the reductive peak current can be used for DNA analysis with satisfactory results. This new electrochemical method was simple, convenient and practical with good selectivity.

\section{Acknowledgements}

Grants from the National Natural Science Foundation of China (20405008, 20375020) and the Natural Science Foundation of Qingdao City (04-2-JZ-114) supported this project.

\section{References}

1. E. Tuite and B. Norden, J. Am. Chem. Soc., 1994, 116, 7548.

2. F. F. Chehab and W. Kan, Proc. Natl. Acad. Sci., 1989, 86, 9178.

3. C. Z. Huang, Y. F. Li, D. J. Zhang, and X. P. Ao, Talanta, 1999, 49, 495.

4. Q. E. Cao, Y. Zhao, Y. Xu, C. Li, Z. Hu, and Q. Xu, Anal. Biochem., 2000, 277, 214.

5. A. P. Abel, M. G. Weller, G. L. Duveneck, M. Ehrat, and H. M. Widme, Anal. Chem., 1996, 68, 2905.

6. R. T. Liu, J. H. Yang, X. Wu, and T. Hu, Anal. Chim. Acta, 2001, 448, 85 .

7. H. W. Gao, Chin. J. Chem., 2003, 21, 170.

8. S. P. Liu, R. Yang, and Q. Liu, Anal. Sci., 2001, 17, 243.

9. C. Z. Hang, Y. F. Li, and P. Feng, Talanta, 2001, 55, 321.

10. E. Arzum, K. Kagun, M. Burca, and O. Mehomet, Electroanalysis, 2001, 13, 219.

11. M. T. Carter, M. Rodriguez, and A. J. Bard, J. Am. Chem. Soc., 1989, 111, 8901.

12. D. W. Pang and H. D. Abeuna, Anal. Chem., 2000, 72, 4700.

13. S. F. Wang, T. Z. Peng, and C. F. Yang, Electroanalysis, 2002, 14, 1648.

14. K. Jiao, Q. J. Li, W. Sun, and Z. J. Wang, Electroanalysis, 2005, 17, 997.

15. F. Jelen, A. Erden, and E. Palecek, Bioelectrochemistry, 2002, 55, 165.

16. W. Sun and K. Jiao, Talanta, 2002, 56, 1073.

17. W. Sun, K. Jiao, X. L. Wang, and L. D. Lu, Electroanalysis, 2005, 17, 62.

18. M. K. Obayashi, T. Kusakawa, M. Saito, S. Kaji, M. Oomura, S. Iwabuchi, Y. Morita, Q. Hasan, and E. Tamiya, Electrochem. Commun., 2004, 6, 337.

19. J. Da and C. Z. Huang, Chin. J. Anal. Chem., 1999, 27, 1204.

20. E. C. Long and J. K. Barton, Acc. Chem. Res., 1990, 23, 271.

21. M. T. Carter and A. J. Bard, J. Am. Chem. Soc., 1987, 109, 7528.

22. R. Marisol and A. J. Bard, Anal. Chem., 1990, 62, 2658.

23. S. Rauf, J. J. Gooding, K. Akhtar, M. A. Ghauri, M. Rahman, M. A. Anwar, and A. M. Khalid, J. Pharm. Biomed. Anal., 2005, 37, 205.

24. M. Fojta, Electroanalysis, 2002, 14, 1449.

25. A. Erdem and M. Ozsoz, Electroanalysis, 2002, 14, 965.

26. Q. Feng, N. Q. Li, and Y. Y. Jiang, Anal. Chim. Acta, 1997, $344,97$.

27. H. M. Zhang, Z. W. Zhu, and N. Q. Li, Fresenius J. Anal. Chem., 1999, 363, 408.

28. Z. W. Zhu and N. Q. Li, Mikrochim. Acta, 1999, 130, 301. 